\title{
Modal Kultural Kakantaran Tombulu Sako Meleng Ulalan Lampangan
}

\author{
Christo Pua \\ christopua@gmail.com \\ Anatje Palit \\ anatjetinekepalit@gmail.com \\ Rafael Terok \\ rafaelterok@gmail.com
}

\begin{abstract}
The contents of the traditional cultural include social resources and cultural capital. This writing is only limited to cultural capital. Cultural capital is a traditional capital, cultural value and norm also local wisdom used to empowered human life in order to make a peaceful and prosperous society. The paradigm of this research is in the form of qualitative research because in this study the form and meaning of the text of a song was explored, found, disclosed, and explained. The form is related to the structure of the text morphologically, whereas the meaning is related to the content that is understood as a value, norm, or local wisdom. Thus, the purpose of this paper is to describe 1) the morphological form of Kakantara Tombulu sa ko meleng ulalan lampangan, and 2) the contents or meanings related to values, norms, local wisdom in the song. Data collection is done by observation and interviews. The observers are the perpetrators of this oral tradition especially when they sing this song together (the atmosphere of joy displayed), and the listeners or connoisseurs of this tradition (passive audience). Interviews were carried out to informants who played an active role or as perpetrators of oral traditions. These observations and interviews were carried out in the city of Tomohon, precisely in the Kakaskasen area, which according to the writer's observation they sing the songs in Tombulu language actively. The result of the study shows that the song of Sa ko meleng lampangan was the thanksgiving song of the ethnic Tombulu who had 1) the structure of the language morphologically morphophemis and has polymorphic morpheme. Thus, this morphological process (affixation and reduplication) forms a new meaning or reinforces the meaning as mentioned by the basic word; 2) Cultural capital can be seen in the form of cultural values and norms which are reflected through the values of faith, brotherhood, friendship, and sincerity implemented by the practitioners or connoisseurs of oral tradition which is bound by certain norms and has become the source of peace and prosperity as the core of local wisdom of the people of Tombulu.
\end{abstract}

Keywords: cultural capital: values, norms, local wisdom 


\begin{abstract}
Abstrak
Isi tradisi budaya mencakup modal sosial (social capital) dan modal kultural (cultural capital). Tulisan ini hanya dibatasi pada modal kultural. Modal kultural adalah tradisi budaya, nilai dan norma budaya serta kearifan lokal yang digunakan untuk memberdayakan kehidupan manusia dalam rangka menciptakan masyarakat yang damai dan sejahtera. Paradigma penelitian ini berbentuk penelitian kualitatif karena dalam kajian ini digali, ditemukan, diungkapkan, dan dijelaskan bentuk dan makna. Bentuk yang dimaksudkan berkaitan dengan struktur teks secara morfologis. Makna berkaitan dengan is yang dipahami sebagai nilai, norma, atau kearifan lokal. Dengan demikian, tujuan tulisan ini, hasilnya mendeskripsikan 1) bentuk morfologis kakantara Tombulu sa ko meleng ulalan lampangan, dan 2) isi/makna yang berkaitan dengan nilai, norma, kearifan lokal dalam lagu tersebut. Pengumpulan data dilakukan dengan observasi dan wawancara. Yang diobservasi adalah para pelaku tradisi lisan ini terutama ketika mereka menyanyikan nyanyian ini (suasana keceriaan yang ditampilkan) secara bersama dan pendengar/penikmat tradisi ini (pasif). Wawancara dilakukan kepada informan yang berperan aktif atau sebagai pelaku tradisi lisan. Observasi dan wawanvara ini dilakukan di kota Tomohon, tepatnya di wilayah Kakaskasen yang menurut pengamatan penulis aktif menyanyikan nyanyian berbahasa Tombulu. Hasil penelitian diperoleh bahwa dalam nyanyian sa ko meleng ulalan lampangan merupakan nyanyian syukur etnis Tombulu yang memiliki 1) struktur bahasa yang secara morfologis bermorfe monomorfemis dan bermorfem polimorfemis. Dengan demikian, proses morfologis ini (afiksasi dan reduplikasi) membentuk makna baru atau mempertegas makna sebagaimana yg disebutkan oleh kata dasarnya. 2) modal kultural tampak dalam bentuk nilai dan norma budaya yang tercermin melalui nilai keimanan, rasa persaudaraan, persahabatan, dan ketulusan di antara pelaku/penikmat tradisi lisan ini, yang diikat oleh norma-norma tertentu, muaranya pada kedamaian dan kesejahteraan yang merupakan inti kearifan lokal masyarakat Tombulu.
\end{abstract}

\title{
PENDAHULUAN
}

Kata Tombulu mengacu pada etnis dan bahasa yang kaya dengan nyanyian rakyat. Masyarakatnya senang dengan bernyanyi. Nyanyian dalam bahasa Tombulu dikenal dengan zazanian; mahzani 'menyanyi' dan kakantaren; mahkantar 'menyanyi' tampaknya memiliki sedikit perbedaan. Mahzani 'menyanyi' dilakukan dalam situasi yang formal atau situasi tertentu dan liriknya kurang panjang. Mahkantar 'menyanyi' dilakukan lebih bebas dan liriknya pun agak panjang. Kakantaren adalah nyanyianuntuk menunjuk semua jenis lagu dari agama Kristen, baik yang dinyanyikan di gereja maupun dalam semua pertemuan keagamaan lainnya. Mulanya lagu-lagu gereja berupa mazmur, tahlil, dari bahasa Belanda ke bahasa lokal. Fungsi kakantaren adalah untuk memuji kebesaran Tuhan dalam berbagai sendi kehidupan manusia. Filsafat Musik Minahasa dalam https://kebudayaan.kemdikbud.go.id 
Nyanyian rakyat/lagu rakyat (folksongs) merupakan salah satu bentuk tradisi budaya/lisan yang memiliki kekayaan nilai, norma, dan kearifan lokal. Dalam tradisi lisan terkandung modal sosial dan modal kultural atau modal sosiokultural. Modal sosial (social capital) diartikan sebagai deposit norma, jaringan, dan kepercayaan yang dianut masyarakat untuk mengkonsepkan sumber daya manusia dalam rangka memberdayakan kehidupan masyarakat. Modal kultural (cultural capital) adalah tradisi budaya, nilai dan norma budaya serta kearifan lokal yang dapat digunakan untuk memberdayakan kehidupan manusia dalam rangka menciptakan masyarakat yang damai dan sejahtera. (Sibarani 2012). Tulisan ini hanya dibatasi pada modal kultural, lebih khusus pada kakantaran Tombulu "sa ko meleng ulalan lampangan".

Paradigma penelitian ini adalah penelitian kualitatif karena dalam kajian ini digali, ditemukan, diungkapkan, dan dijelaskan bentuk dan makna kakantaren Tombulu. Bentuk yang dimaksudkan berkaitan dengan struktur teks dalam kajian linguistik, yakni secara morfologis. Makna yang dimaksudkan berkaitan dengan isi/meaning (makna) yang dipahami sebagai nilai, norma, atau kearifan lokal. Hal ini pun secara tidak langsung menjelaskan modal kultural yang dimaksudkan penulis sesuai judul tulisan ini. Dengan demikian, tujuan tulisan ini, yakni mendeskripsikan 1) bentuk morfologis kakantara Tombulu sa ko meleng ulalan lampangan, dan 2) isi/makna yang berkaitan dengan nilai, norma, kearifan lokal dalam lagu tersebut.

Pengumpulan data dilakukan dengan observasi dan wawancara. Yang diobservasi adalah para pelaku tradisi lisan ini terutama ketika mereka menyanyikan nyanyian ini (suasana keceriaan yang ditampilkan) secara bersama dan pendengar/penikmat tradisi ini (pasif). Wawancara dilakukan kepada informan yang berperan aktif atau sebagai pelaku tradisi lisan. Observasi dan wawanvara ini dilakukan di kota Tomohon, tepatnya daerah Kakaskasen yang menurut pengamatan penulis aktif menyanyikan nyanyian berbahasa Tombulu. Selanjutnya, teori yang diacu berkaitan dengan aspek morfologis sesuai konsep Alwi, dkk (2003), dan berkaitan dengan nilai, norma, kearifan lokal diacu konsep Sibarani (2012). 


\section{Lirik dan Terjemahan}

\section{Sako Meleng Ulalan Lampangan}

Sako meleng ulalan lampangan 'kalau kamu/kau pilih jalan untuk dijalani'

Gumenang-genang wo karia 'ingat-ingat dengan teman'

Umengalei-ngalei wia si mapiara 'memohon-mohon kepada Yang memelihara hidup'

Turuame lalan kaleos-leosaneaku 'tujukkanlah jalan yang baik-baik'

Tia iwali-wali ndotu'u 'tidak dibawa-bawa kasihan'

Witu lalan kalewo-lewoan 'ke jalan yang jahat/sukar/tidak baik'

Satoro pengilek-ileken neaku 'kalau bisa/sekiranya boleh lindung-lindungi aku'

Nitakaria nania wo mange 'bersama semua teman di sini untuk pergi'

Ndootu'u tia kiit-kiiten 'jangan ikut-ikutan kasihan'

Witu kasalaanku 'itu kesalahanku'

Reff.

Si Tuhan Yesus engkimua 'itu Tuhan Yesus berkata'

Mangemo kamu mamenero 'pergilah kamu mencari'

Setou lengei liur tamburi 'orang lemah yang lupa di masa lalu'

Wo'o menero ung kamangna 'dan mencari berkat'

Ya...tawane tawane 'ya, panggillah panggillah'

Wo me'e remoken 'dan pergi kumpulkan'

Ungkamang wangko 'berkat besar'

Wia nyaku... wia nyaku 'bersamaku bersamaku'

Hasil dan Pembahasan

\section{HASIL DAN PEMBAHASAN}

Lirik lagu ini cukup panjang karena terdapat lebih dari sepuluh baris, yang antara lain memuat kisah dan pandangan hidup orang Tombulu tentang pilihan jalan hidup yang mengarah pada kebaikan, bukan hanya untuk dirinya melainkan juga untuk orang-orang yang ada di sekitarnya.

\section{Analisis Lingual}

Tampak dalam lingkup linguistik tataran kelas kata lirik Sako Meleng Ulalan Lampangan terdapat bentuk nomina, verba, dan adjektiva, adverbial, dan kata tugas seperti pada tabel berikut ini.

\begin{tabular}{|c|c|c|c|c|}
\hline Nomina & Verba & Adjektiva & Adverbial & kata tugas \\
\hline $\begin{array}{l}\text { Ko 'kau/kamu' } \\
\text { karia 'teman' } \\
\text { Kamu 'kalian' } \\
\text { Tou 'orang', } \\
\text { Nyaku 'aku' }\end{array}$ & $\begin{array}{l}\text { Meleng'pilih' } \\
\text { Mange 'pergi' } \\
\text { Me'e 'pergi' } \\
\text { kimua 'dikatakan' } \\
\text { kata dasar kua }\end{array}$ & $\begin{array}{l}\text { Ndootu'u } \\
\text { Lengei 'lemah' } \\
\text { Liur 'lupa' } \\
\text { wangko 'besar' }\end{array}$ & $\begin{array}{l}\text { Sa 'kalau' } \\
\text { Witu 'di } \\
\text { situ' } \\
\text { Wia'di sini' }\end{array}$ & $\begin{array}{l}\text { wo;wo'o } \\
\text { 'dan/deng } \\
\text { an' } \\
\text { mo 'lah' } \\
\mathrm{Si}\end{array}$ \\
\hline
\end{tabular}




\begin{tabular}{|c|c|c|c|c|}
\hline $\begin{array}{l}\text { Kamang } \\
\text { 'berkat' } \\
\text { Kamangwangko } \\
\text { 'berkat besar' } \\
\text { lalan 'jalan' }\end{array}$ & $\begin{array}{l}\text { 'bilang' mendapat } \\
\text { infiks -im- yang } \\
\text { berarti telah. Jadi } \\
\text { kimua 'telah bilang' } \\
\text { sama dengan } \\
\text { dikatakan. } \\
\text { mangemo 'pergilah'. } \\
\text { mo pada mangemo } \\
\text { merupakan partikel } \\
\text { penegas. } \\
\text { Mamenero asal kata } \\
\text { sero'cari' mendapat } \\
\text { prefix me- menjadi } \\
\text { menero 'mencari' } \\
\text { dan mendapatkan lagi } \\
\text { prefix ma- menjadi } \\
\text { mamenero 'pergi } \\
\text { mencari'. Bentuk } \\
\text { mamenero } \\
\text { merupakan verba } \\
\text { transitif, yakni diikuti } \\
\text { objek. } \\
\text { Mapiara kata } \\
\text { dasarnya piara } \\
\text { 'pelihara' dan } \\
\text { mendapat a prefix } \\
\text { ma- menyatakan aktif } \\
\text { 'memelihara' } \\
\text { tawane 'panggilkan' } \\
\text { lampangan' } \\
\text { mengalei-ngalei } \\
\text { Turuame } \\
\text { iwali-wali } \\
\text { kiit-kiiten } \\
\text { remoken } \\
\text { pengilek-ileken }\end{array}$ & $\begin{array}{l}\text { kaleos-leosan } \\
\text { bentuk dasar leos } \\
\text { 'baik' yang } \\
\text { dilekati konfiks } \\
\text { ke-an pada } \\
\text { reduplikasi leos } \\
\text { menjadi kaleos- } \\
\text { leosan 'keadaan } \\
\text { baik-baik'. } \\
\text { kalewo-lewoan } \\
\text { bentuk dasar } \\
\text { lewo 'jahat' yang } \\
\text { dilekati konfiks } \\
\text { ka-an pada } \\
\text { reduplikasi lewo } \\
\text { menjadi kalewo- } \\
\text { lewoan 'keadaan } \\
\text { jahat' } \\
\text { gumenang- } \\
\text { genang bentuk } \\
\text { dasar genang } \\
\text { 'ingat' yang } \\
\text { mendapat infiks - } \\
\text { um- menjadi } \\
\text { gumenang 'akan } \\
\text { ingat' kemudian } \\
\text { direduplikasikan } \\
\text { bentuk dasar } \\
\text { tersebut menjadi } \\
\text { gumenang } \\
\text { genang 'akan } \\
\text { ingat-ingat' }\end{array}$ & $\begin{array}{l}\text { nania 'hari } \\
\text { ini' } \\
\text { tamburi } \\
\text { 'lama/belak } \\
\text { ang' }\end{array}$ & $\mathrm{Se}$ \\
\hline
\end{tabular}

Kelas nomina (kata benda) yang ada dalam lirik berbentuk dasar. Bentuk dasar tersebut umumnya sebagai kata ganti orang: ko 'kau', karia 'teman', kamu 'kamu', tou 'orang', nyaku 'aku', kamang/kamangwangko 'berkat besar', baik yang menyatakan tunggal maupun jamak, yang menyatakan manusia dan menyatakan Tuhan. Bervariasinya 
pilihan kata ini menunjukkan pula penyair/pencipta menunjuk kepada semua yang mendiami kosmos sebagai subjek.

Kelas verba (kata kerja) dalam lirik sangat variatif, ada yang berbentuk dasar dan ada yang berbentuk afiks, bahkan reduplikasi. Bentuk dasar, seperti meleng 'pilih', mange 'pergi', me'e 'pergi'. Bentuk afiks: prefix: mapiara (ma-)'yang mengatur/memelihara'; infiks: kimua (-im-) 'telah dikatakan'; rewoken (-en) 'dikumpulkan'. Bentuk verba menyatakan apa yang dilakukan subjek atau menunjukkan suatu peristiwa atau keadaan dari apa/hal yang akan dijelaskan. Bentuk reduplikasi berfungsi mempertegas apa yang dimaksudkan pada kata dasarnya apalagi reduplikasi terjadi secara penuh bukan reduplikasi parsial.

Kelas adjektiva (kata sifat) dalam lirik berbentuk dasar dan reduplikasi berafiks. Ajektiva bentuk dasar, seperti lengei, liur, wangko dan reduplikasi berafiks (konfiks dan infiks), seperti kaleos-leosan 'paling baik', kalewo-lewoan 'paling jahat', dan gumenanggenang 'akan dikenang-kenang'. Adjektiva menyatakan sifat atau keadaan suatu hal, semisal makluk hidup, benda mati, tempat, waktu atau lainnya. Fungsi adjektiva selain menjelaskan keadaan subjek atau objek dalam kalimat, juga menyatakan kualitas atau kuantitas dari apa yang diterangkan.

Kelas adverbia (kata keterangan) dalam lirik menunjuk pada keterangan tempat dan syarat. Keterangan syarat, yakni $S a$ 'apabila' dan keterangan tempat, seperti witu 'di situ', wia 'di sini', tamburi 'di belakang' dan keterangan waktu, yakni nania 'hari ini'. Kata keterangan sifatnya memberikan keterangan/penjelasan tentang suatu hal yang berkaitan dengan waktu, tempat, cara, tujuan, syarat, alat, sebab, akibat, dll. Hal ini dilakukan untuk menyatakan suatu maksud secara lengkap dan jelas.

Kelas kata tugas dalam lirik, terdiri atas konjungsi: Wo;wo'o 'dan, dengan'; partikel mo 'lah'; artikel tunggal: Si 'menunjuk pada Tuhan atau seseorang'; artikel kelompok Se 'menunjuk pada lebih dari satu orang'. Kata tugas adalah kata yang hanya memiliki arti gramatikal dan tidak memiliki makna leksikal, sehingga maknanya akan menjadi jelas bila dihubungkan dengan kata lain. Kata tugas dalam bahasa Indonesia melingkupi preposisi, konjungsi, intejeksi, artikel (yang mengacu ke makna tunggal, kelompok, netral), dan partikel.

Berdasarkan apa yang telah dideskripsikan di atas, ditunjukkan bahwa lirik Sako meleng ulalan lampangan sangat variatif dari aspek linguistik. Hal ini memberi kesan 
bahwa pesan yang ingin disampaikan pembaca bukan sekedar himbauan atau ajakan, tetapi sebuah tuntutan, yakni jika mau menjalani hidup mintalah kepada Sang pemberi hidup jalan yang terbaik menurut-Nya bukan menurut kita. Bentuk nomina kata ganti orang, tunggal dan jamak yang mendominan lirik ini sehingga yang menjadi pokok pembicaraan yakni manusia sebagai makluk hidup dan pemberi hidup (Tuhan). Bentuk verba aktif, pasif pun tampak, yang memberi tanda aktif pasifnya subjek melakukan sesuatu. Demikian pula dengan waktu, ditunjukkan baik yangtelah, sementara, dan akan yang merupakan/ menjadi satu totalitas.

\section{Analisis Modal Kultural}

Modal kultural (cultural capital) yang diacu dalam tulisan ini didasari oleh pemikiran Sibarani (2012) yang disitir sebagai berikut. Modal kultural adalah tradisi budaya, nilai dan norma budaya serta kearifan lokal yang dapat digunakan untuk memberdayakan kehidupan manusia dalam rangka menciptakan masyarakat yang damai dan sejahtera. Modal kultural berperan dalam memberdayakan masyarakat ketika modal kultural dipandang sebagai deposit tradisi budaya seperti tradisi lisan dengan semua nilainilai budaya yang dapat dimanfaatkan, baik untuk membangun kepribadian yang kuat juga dalam penciptaan kedamaian hidup. Dalam kaitan itu, pengetahuan yang dapat digali dalam hubungannya dengan modal kultural, berupa: 1) cara-cara penggunaan (usage), 2) kebiasaan rakyat (folksways), 3) moral dan etika (mores and etics), 4) norma (norms), 5) adat-istiadat (custom), 6) keterampilan (skill), dan 7) kompetensi atau pengetahuan (competence).

Atas dasar itulah, modal kultural merupakan tradisi lisan atau tradisi budaya yang memiliki nilai budaya dan norma budaya yang dapat dikatakan sebagai kearifan lokal, dimanfaatkan untuk memberdayakan manusia dalam rangka meningkatkan kesejahteraan manusia dan menciptakan kedamaian hidup.

\section{Nilai dan Norma Budaya}

Nilai dan norma budaya merupakan dua kata yang mengemban makna berbeda. Secara umum, nilai adalah sesuatu yang menyangkut baik dan buruk, sedangkan norma adalah sesuatu yang menyangkut benar dan salah. Istilah nilai terkadang digunakan orang dengan mengacu pada sesuatu yang baik dan benar, sehingga kata nilai mencakup 
keduanya. Sistem nilai dan norma dapat dkatakan sebagai pedoman standar yang berlaku dalam kehidupan bermasyarakat, begitu kuat meresap dan berakar dalam jiwa masyarakat sehingga menjadi bagian dari keyakinannya (Sibarani, 2012: 178-179). Dalam bagian yang lain, Theodore (1979:455) berpendapat bahwa nilai merupakan sesuatu yang abstrak, dijadikan pedoman dan prinsip-prinsip umum dalam bertindak dan bertingkah laku.

Menggali nilai dan norma budaya dari tradisi lisan atau tradisi budaya suatu etnik kemudian mengkategorisasikannya menjadi kearifan lokal. Jenis kearifan lokal diklasifikasi berdasarkan kegunaan nilai budaya untuk menata kehidupan sosial dalam penciptaan kedamaian dan peningkatan kesejahteraan. Dengan demikian, inti kearifan lokal, yakni kearifan lokal kesejahteraan dan kearifan lokal kedamaian. Dalam tulisan ini cenderung pada kearifan lokal kedamaian sesuai dengan objek kajiannya yakni lirik dan makna nyanyian rakyat.

Kakantaran Tombulu "Sako Meleng Ulalan Lampangan" merupakan salah satu jenis modal kultural masyarakat Tombulu yang berupa lagu/nyanyian rakyat yang dinyanyikan dalam acara-acara syukuran, baik suka mapun duka. Lagu ini beredar secara lisan di antara anggota masyarakat tertentu dan banyak variannya serta sumbernya pun dapat beragam. Umumnya yang dipertahankan adalah melodinya sedangkan kata-katanya dapat diganti-ganti sesuai pesan yang ingin disampaikan. Kakantaran Tombulu itu dikategorikan sebagai nyanyian rakyat karena antara lain berciri melodinya mudah diingat dan sangat bervariasi, bahkan mulai dari paling sederhana sampai sulit, juga dapat bertahan pada beberapa generasi. Sebagaimana data ini diambil di Desa Kakaskasen Tomohon yang masyarakatnya penutur bahasa Tombulu, penulis merasakan terkadang informan menyanyikannya dengan kata-kata yang berbeda atau kata-kata yang bersinonim, seperti kata mange dan me'e yang berarti pergi, bahkan ada lirik yang dapat diganti-ganti. Pada suatu acara syukuran mingguan ketika ada keluarga yang meninggal lagu itu dimunculkan/dinyanyikan bersama yang berada dalam kelompok itu generasi 40an dan generasi 60-an.

Bukan hanya itu, ketika dalam kesempatan yang lain, dalam acara keluarga, ada seorang bapak yang berusia 80-an tertidur kaku di tempat tidur, tidak dapat melakukan aktivitas lagi karena stroke, dan istri dari si bapak tersebut meminta keluarga untuk menyanyikan lagu Sako Meleng Ulalan Lampangan, penulis menyaksikan langsung apa 
yang dilakukan si bapak ketika lagu itu akan selesai si bapak meremas dengan susah payah lengan salah seorang keluarga. Istri si bapak tersebut berkata bahwa si bapak itu ingin lagi mendengarkan lagu itu dan minta menyanyikannya dengan perlahan. Ada dorongan berupa luapan emosi yang memberi kesenangan, kedamaian ketika lagu itu diperdengarkan. Ada semangat yang digambarkan lewat lagu itu.

Ekspresi yang ditunjukkan oleh para penyanyi generasi 40-an dan generasi 60-an, bahkan bapak yang terkapar kaku mewakili generasi 80-an menunjukkan lagu ini bernilai tinggi dalam kehidupan masyarakat pendukungnya. Pesan yang ingin disampaikan lewat lagu ini bahwa seseorang yang akan menjalani hidup ada pilihan yang diperhadapkan kepadanya. Pilihan itu dapat saja baik atau jelek, tergantung mana yang mau dipilih dan dijalani. Ajaklah teman/saudara atau siapa saja dalam memilih jalan untuk dijalani dengan terlebih dahulu memohon kepada yang kuasa; si mapiara (dalam teks lagu). Keimanan yang tinggi, rasa persaudaraan, membangun persahabatan adalah sesuatu yang baik, memiliki nilai (value) yang muaranya pada kedamaian. Secara aksiologis, kebaikan bermanfaat untuk menciptakan kedamaian yang mencakup kerukunan, keadilan, kenyamana, dan keamanan dalam suatu komunitas. Apabila orang-orang dalam satu komunitas memiliki kepribadian yang baik, maka komunitas itu akan damai, rukun, nyaman dan aman. Hal ini ditujukkan oleh komunitas generasi 40-an dan 60-an yang sering tampil bersama dalam menyanyikan kakantaran Tombulu pada suatu syukuran sebagaimana disebutkan di atas.

Sa ko meleng ulalan lampangan 'kalau kamu/kau pilih jalan untuk dijalani'

Gumenang-genang wo karia 'ingat-ingat dengan teman'

Umengalei-ngalei wia si mapiara 'memohon-mohon kepada Yang memelihara hidup'

Turuame lalan kaleos-leosaneaku 'tujukkanlah jalan yang baik-baik'

Tia iwali-wali ndotu'u 'tidak dibawa-bawa kasihan'

Witu lalan kalewo-lewoan 'ke jalan yang jahat/sukar/tidak baik'

Selanjutnya, suatu permohonan kepada $s i$

untuk tidak memandang kesalahanku di masa lalu bersama teman-temanku.

Sa toro pengilek-ileken neaku 'kalau bisa/sekiranya boleh lindung-lindungi aku'

Nitakaria nania wo mange 'bersama semua teman di sini untuk pergi'

Ndootu'u tia kiit-kiiten 'jangan ikut-ikutan kasihan'

Witu kasalaanku 'itu kesalahanku' 
Lebih jelas lagi, pada larik berikut ini dinyatakan bahwa Tuhan yang diimani oleh kaum nasrani berpesan agar mencari kaum/orang-orang yang lemah atau yang papah untuk dipanggil, dikumpulkan agar bersama mencari berkat terutama berkat besar yakni keselamatan.

Si Tuhan Yesus engkimua 'itu Tuhan Yesus berkata'

Mangemo kamu mamenero 'pergilah kamu mencari'

Setou lengei liur tamburi 'orang yang lemah/papah, tersesat di waktu lalu'

Wo'o menero ung kamangna 'dan mencari berkat'

Ya....tawane tawane 'ya, panggillah panggillah'

Wo me'e remoken 'dan pergi kumpulkan'

Ungkamang wangko 'berkat besar'

Wia nyaku... wia nyaku 'bersamaku bersamaku'

Berdasarkan pesan yang disampaikan dalam lirik lagu di atas memungkinkan apa yang dimaksudkan dengan kearifan lokal dalam wujud kedamaian benar-benar terwujud dalam lagu ini. Seseorang yang mendengarkan lagu ini atau menyanyikan lagu ini tampak ekspresi senang terwujud dari ketika mereka menyanyikannya tampak kegembiraan yang meluap. Walaupun demikian, ketika lagu ini dinyanyikan aturan (norma) masyarakat menjadi perhatian, artinya harus dapat memperhatikan tempat, waktu, dan siapa yang menjadi pendengarnya. Konsep kedamaian dapat dicapai apabila seseorang setia pada aturan (norma) komunitas dan juga setia pada petujuk agama atau yang diimani. Orang yang berkepribadian baik mampu menyeimbangkan emosinya atau menata emosinya ketika berhadapan dengan seseorang yang terkadang memiliki emosi yang berbeda. Kepribadian seperti ini menjadi syarat utama dalam menciptakan kedamaian.

\section{SIMPULAN}

Nyanyian sa ko meleng ulalan lampangan sebagai nyanyia syukur etnis Tombulu memiliki 1) struktur bahasa yang secara morfologis bermorfem tunggal atau monomorfemis dan bermorfem lebih dari satu atau polimorfemis. Dengan demikian, proses morfologis ini (afiksasi dan reduplikasi) membentuk makna baru atau mempertegas makna sebagaimana yg disebutkan oleh kata dasarnya. 2) modal kultural dalam bentuk nilai dan norma budaya tercermin dalam nyanyian sa ko meleng ulalan lampangan. Meningkatnya nilai keimanan, rasa persaudaraan, persahabatan, dan ketulusan di antara pelaku/penikmat tradisi lisan ini, dengan norma-norma yang berlaku, 
muaranya pada kedamaian dan kesejahteraan yang merupakan inti kearifan lokal masyarakat Tombulu.

\section{Daftar Pustaka}

Alwi, Hasan. dkk. 2003. Tata Bahasa Baku Bahasa Indonesia. Jakarta: Balai Bahasa.

Renwarin, Paul. (ed). 2012. Etnolinguistik Minahasa. Yogyakarta: Kanisius.

Sibarani, Robert. 2012. Kearifan Lokal: Hakikat, Peran, dan Metode Tradisi Lisan.

Jakarta: Asosiasi Tradisi Lisan (ATL)

Tim Peneliti Fakultas Sastra Unsrat.1978. 'Struktur Bahasa Minahasa'. Proyek Penelitian

Bahasa dan Sastra Indonesia dan Daerah Sulut.

Filsafat Musik Minahasa dalam https://kebudayaan.kemdikbud.go.id 